\title{
The Effects of Core Training on Basketball Athletes' Antioxidant Capacity
}

\author{
Recep Soslu ${ }^{1}$, Ömer Özer ${ }^{1}$, İsmail Can Çuvalcioğlu ${ }^{2}$ \\ ${ }^{1}$ Karamanoğlu Mehmetbey University, Physical Education and Sport, Karaman, Turkey \\ ${ }^{2}$ Bartın University, Physical Education and Sport, Bartın,Turkey \\ Correspondence: Recep Soslu, Karamanoğlu Mehmetbey University, Physical Education and Sport, Karaman, Turkey.
}

Received: July 20, 2018

Accepted: September 15, 2018

Online Published: September 17, 2018

doi:10.11114/jets.v6i11.3454

URL: https://doi.org/10.11114/jets.v6i11.3454

\begin{abstract}
Core strength is defined as producing or protecting the strength, and putting against a resistance. Exercise can cause free radical formation according to its intensity and duration which increase metabolic processes and oxygen consumption. Oxidative stress, muscle fatigue, muscle damage and its pain because of this increase are related with decreasing physical performance. Purpose of this study was to investigate effects of core training on antioxidant system. Participants of this study were 13 basketball players who accepted to attend voluntarily. Mean heights of participants were $175.73 \pm 4.26$ and mean weights of them were $63.61 \pm 5.48$. Group followed 8 weeks core training three times a week and 2 hours for each time. Venous blood samples were taken from participants at the end of first, fourth and eighth week trainings. Samples were analyzed according to Antioxidan(Superoxide Dismutase(SOD), Glutatyon Peroksidaz(Gsh-Px), Catalase(CAT) and Malondialdehyde(MDA) parameters. Data were analyzed with Multivariate ANOVA and bonferroni follow-up tests. Results showed that second and third SOD values were significantly higher than first test SOD value before core training process $(F(2)=7.08$, p <0.05). Even increase happened, there were not statistically significant difference on GSH $(F(2)=2.57, \mathrm{p}>0.05)$ and CAT $(F(2)=2.80, \mathrm{p}>0.05)$ values. Moreover, second and third MDA values statistically significant decreased according to MDA first test value $\left(F\left({ }_{2}\right)=7.43, \mathrm{p}<0.05\right)$. As a conclusion, core exercises increased oxygen consumption which causes free radical formation. It was determined that detrimental effects of this free radical formation were repressed by increasing SOD activity value and it decreased MDA which is free radical parameters. It is thought that increasing antioxidant level via exercise can effect athletes' performances positively.
\end{abstract}

Keyword: core training, antioxidant, oxidative stress

\section{Introduction}

Physiologically, core strength and stability trainings lead to a greater maximal power and more effective use of the muscles of the shoulders, arms and legs (Lehman, 2006). This theoretically results in a better body balance and a lower risk of injury, leading to additional effects on performance, such as speed, agility, power and aerobic endurance (Tse, McManus \& Masters, 2005). Neural adaptations from core training include; more efficient neural recruitment patterns, faster nervous system activation, improved synchronisation of motor units and lowering neural inhibitory reflexes (Stoke, Hides \& Nassiri, 1997). It is believed that high-load training alters the muscle structure, whereas low-load training improves the Central Nervous System's ability to control muscle co-ordination and therefore the effectiveness of the movement (Comerford, 2006). Subsequently improvements of low and high-load exercises should be supported by core stability and core strength exercises which benefit athletes' sporting performance (Stephenson \& Swank, 2004).

Exhaustive physical exercise is characterized by a dramatic increase in oxygen consumption of the whole body and particularly of the skeletal muscle, which from $2 \%$ to $5 \%$ of it is not completely reduced to water in the mitochondria; instead under going an univalent reduction to produce superoxide radicals that could subsequently leak out of the electron transport chain (Banerjee, Mandal, Chanda \& Chakraborti, 2003). Although oxidative stress has been related to the pathophysiology of several diseases such as atherosclerosis, diabetes and cancer (Knez, Jenkins \& Coombes, 2007), there is, irrefutable evidence that regular physical activity is a very important deterrent of such conditions (Warburton, Nicol \& Bredin, 2006). Actually, regular exercise (training) causes physiologic adaptations that enhance antioxidant defences and could minimize oxidative stress either in resting conditions and in response to acute exercise (Selamoğlu, Turgay, Kayatekin, Gönenc \&Yslegen, 2003; Akdemir, Gülçin, Karagöz, Soslu \& Alwasel, 2017). It has been described that aerobic and anaerobic trainings induce an enhancement in the activity of antioxidant enzymes, mainly of 
superoxide dismutase (SOD) and glutathione-peroxidase (GPx) (Selamoğlu et al., 2003; Palazetti, Richard, Favier \& Margaritis, 2003). Thus, athletes generally present an up-regulated antioxidant enzymes activity in comparison with non-trained subjects (Evelson, Gambino, Travacio, Jaita, Verona \& Maroncelli, 2002; Robertson, Maughan, Duthie \& Morrice, 1991). Consequently, individuals training regularly may improve an overall antioxidant status and protect themselves against oxidative stress when comparing with healthy sedentary subjects (Cazzola, Russo-Volpe, Cervato \& Cestaro, 2003).This study was planned to determine the effects of core training basketball players on antioxidant capacity.

\section{Materials and Methods}

\subsection{Subjects}

Participants of this study were 13 male basketball players who accepted to attend voluntarily. Mean heights of participants were $175.73 \pm 4.26$, mean ages of them $20.88 \pm 1.05$ and mean weights of them were $63.61 \pm 5.48$.

\subsection{Exercise Protocol}

Core stability and core strength exercises were performed. The exercises were selected based on previous research that high lights them as important in developing core stability and core strength(Urguhart \& Hodges, 2005;Anderson $\&$ Behm 2004). These included low threshold (less demanding, posture related exercises which focus on muscle recruitment) and high threshold exercises (greater stress on the core musculature thus promoting core strength development). The exercises are classified twice or triple. The core exercises were performed continually for one minute rest between the sets. The order that the exercises were performed in was a cross over randomised design for each subject. The duration and number of repetitions over which these exercises were performed varied due to the demands of the exercises (Table 1) but these were subsequently time-normalised to muscle activity per second to enable direct comparisons between the exercises. Repetition rates were determined by a coach and monitored using a stop watch.

Table 1. Core Training Programme

\begin{tabular}{|c|c|c|c|c|c|c|c|c|c|}
\hline \multirow{2}{*}{$\begin{array}{l}\text { Exercise } \\
\text { Progression }\end{array}$} & \multirow{2}{*}{ Progression } & \multicolumn{2}{|c|}{ Week 1-2 } & \multicolumn{2}{|c|}{ Week 3-4 } & \multicolumn{2}{|c|}{ Week 5-6 } & \multicolumn{2}{|c|}{ Week 7-8 } \\
\hline & & Repetitions & Sets & Repetitions & Sets & Repetitions & Sets & Repetitions & Sets \\
\hline Forward bridge & Volume & 30 sec hold & 2 & 60 sec hold & 2 & 90 sec hold & 2 & 120 sec hold & 2 \\
\hline Side bridge & Volume & 30 sec hold & 2 & 60 sec hold & 2 & 90 sec hold & 2 & 120 sec hold & 2 \\
\hline Birddog & Volume & 10 & 3 & 15 & 3 & 20 & 3 & 25 & 3 \\
\hline Leg raise & Volume & 10 & 3 & 15 & 3 & 20 & 3 & 25 & 3 \\
\hline Shoulder press & Volume & 10 & 3 & 10 & 4 & 15 & 4 & 20 & 3 \\
\hline Overhead squat & Load & $10(3 \mathrm{~kg})$ & 3 & $10(4 \mathrm{~kg})$ & 3 & 15 (5kg) & 3 & 20 (6kg) & 3 \\
\hline Sit twist Load & Load & 15 (3kg) & 3 & 15 (4kg) & 3 & $15(5 \mathrm{~kg})$ & 3 & 20 (6kg) & 3 \\
\hline
\end{tabular}

\subsection{Blood Analysis}

Blood samples were taken triple just before(pre), middle(mid) and after(post) the exercise and these blood samples were taken after training period of 8 weeks. The levels of serum SOD, GSH, CAT and MDA were determined on the neparinize blood samples taken from venous. The blood samples were taken before and after burden.

\subsubsection{Blood Samples}

Blood was collected from the antecubital vein at the fasted state at 07:30-08:00 a.m., approximately $20 \mathrm{ml}$ to each of 2 sample tubes. Some donations were used to determine the parameters of blood count with differential. The remaining plasma samples were collected, frozen at $-80 \mathrm{C}$, and kept in these conditions until biochemical measurements. Determination of the cellular components of blood was conducted on a hematology analyzer BC-2800 Mindray's. Blood smears were evaluated independently. The activity of catalase (CAT) was determined by the set of reagents OxiSelect Catalase Activity Assay Kit, (No. Cat. STA-341) produced by the Cell Biolabs company. The activity of Superoxide Dismutase (SOD), Glutathione Assay Kit GSH and malondialdehyde concentration was performed using reagents from kits Cayman Chemical Company: Superoxide Dismutase Assay Kit (No. Cat. 706,002), Antioxidant Assay Kit (No. Cat. 703,002) and TBARS Assay kit (No. Cat. 10,009,055). All assays were performed strictly according to the instructions included by the manufacturer.

\subsection{Statical Analyze}

Data were analyzed with Multivariate ANOVA and bonferroni follow-up tests. 


\section{Results}

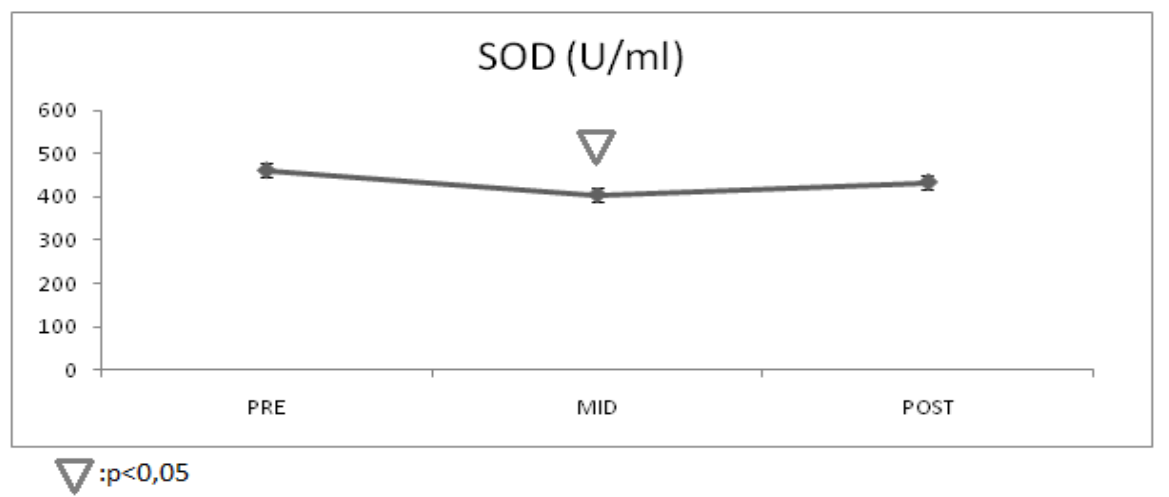

Graph 1. Pre, mid and post SOD levels of basketball players

When Graph 1 is examined, the pre-, mid- and post-SOD (U/ml) data of the players is determined as $461.84 \pm 147.79$ $(\mathrm{U} / \mathrm{ml}), 404.61 \pm 122.84(\mathrm{U} / \mathrm{ml})$ and $434.18 \pm 131.80(\mathrm{U} / \mathrm{ml})$, respectively. A statistically significant reduction in the mid measurement is found compared to the pre and post measurements $(\mathrm{p}<0.05)$.

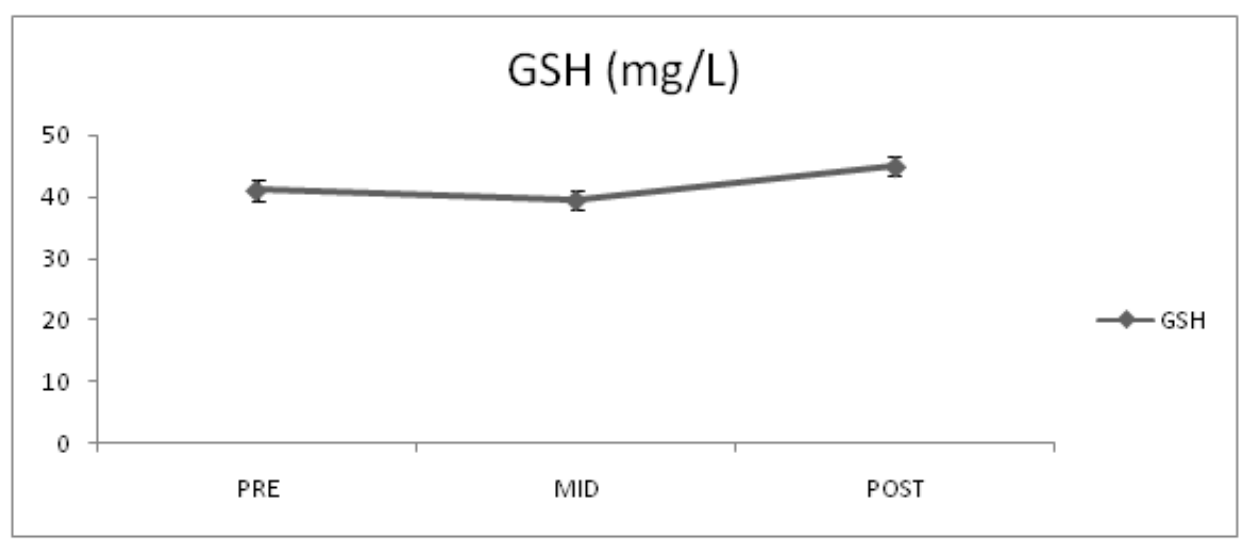

Graph 2. Pre, mid and post GSH levels of basketball players

When Graph 2 is examined, the pre-, mid- and post-GSH (mg/L) data of the players is determined as $41.06 \pm 13.14$ $(\mathrm{mg} / \mathrm{L}), 39.5 \pm 11.99(\mathrm{mg} / \mathrm{L})$ and $44.91 \pm 13.63(\mathrm{mg} / \mathrm{L})$, respectively. A statistically significant reduction is not found in the pre, mid and post measurements $(\mathrm{p}>0.05)$.

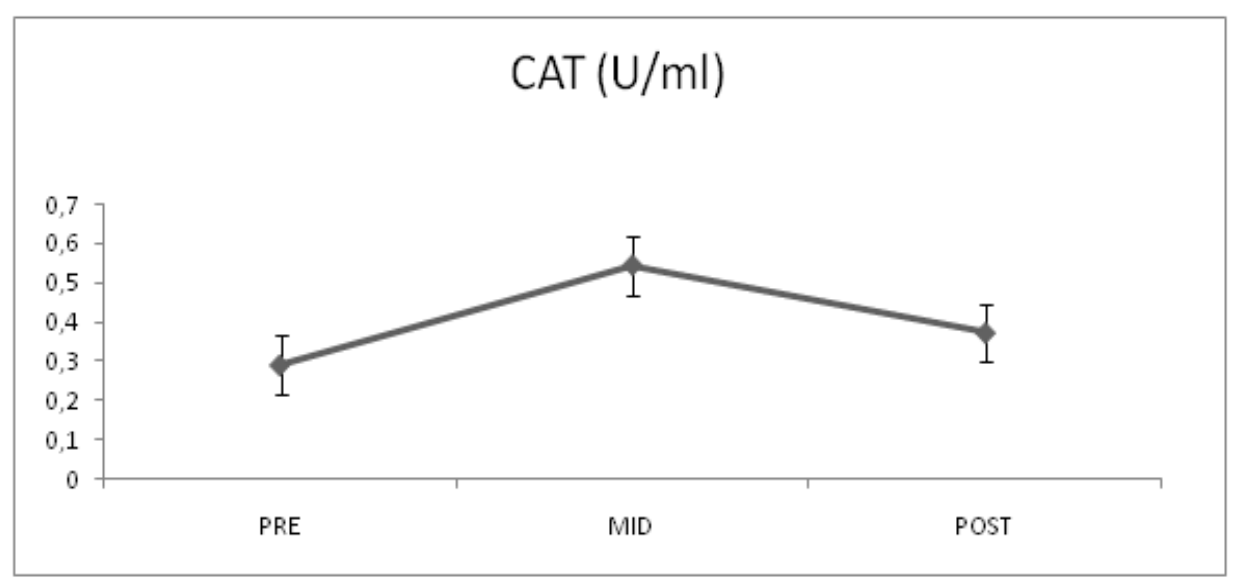

Graph 3. Pre, mid and postCAT levels of basketball players

When Graph 3 is examined, the pre, mid and postCAT $(\mathrm{U} / \mathrm{ml})$ data of the players is determined as $0.29 \pm 0.09(\mathrm{U} / \mathrm{ml})$, $54 \pm 0.17(\mathrm{U} / \mathrm{ml})$ and $0.37 \pm 0.11(\mathrm{U} / \mathrm{ml})$, respectively. A statistically significant reduction is not found in the pre, mid and post measurements $(\mathrm{p}>0.05)$. 


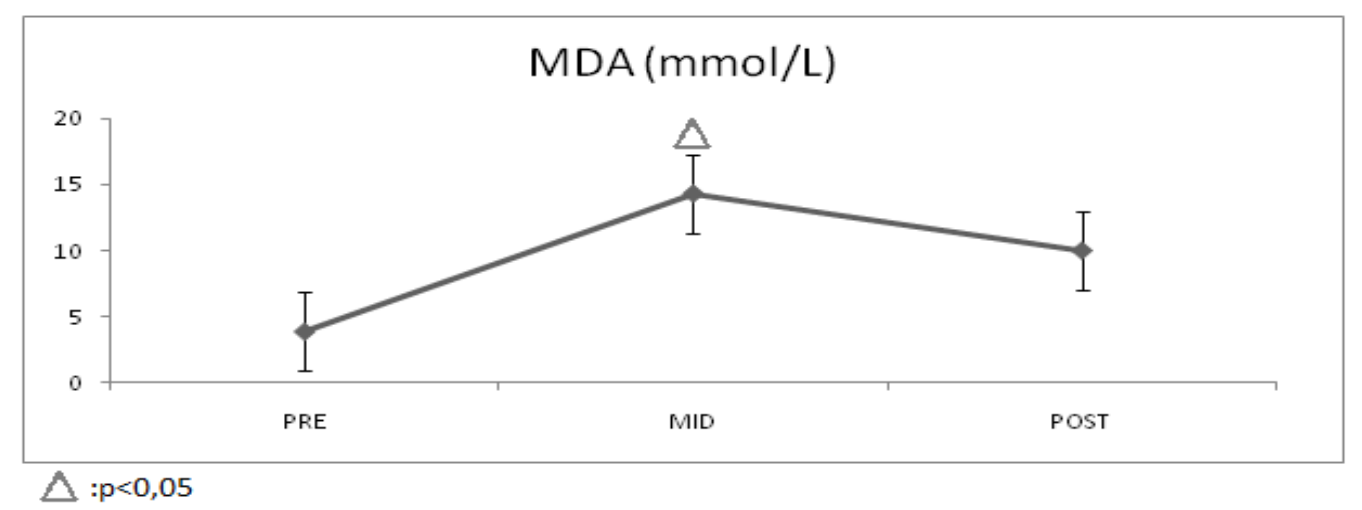

Graph 4. Pre, mid and postMDA levels of basketball players

When Graph 4 is examined, the pre-, mid- and post-MDA (mmol/L) data of the players is determined as $3.91 \pm 1.18$ $(\mathrm{mmol} / \mathrm{L}), 14.27 \pm 4.12(\mathrm{mmol} / \mathrm{L})$ and $9.99 \pm 2.89(\mathrm{mmol} / \mathrm{L})$, respectively. A statistically significant reduction in the mid-measurement is found compared to the pre and post-measurements $(\mathrm{p}<0.05)$.

\section{Discussion}

In an intense and heavy exercise, the oxygen flow in skeletal muscle increases significantly, and the amount of ATP consumption exceeds the ATP generation. This metabolic stress in the cells significantly increases the free radical production. Under normal conditions, free radicals are produced at a lower rate and allow the antioxidant system to develop. However, if free radicals are excessively produced, the capacity of cellular defense system is exceeded and eventually cell viability is damaged. As a result, intense exercise causes muscle damage and inflammation (Taş 2011; Gülçin 2010).

Serum SOD level is one of the most important enzymatic antioxidants fighting against superoxide radicals in the cell (Kıyıc1 \& Kishal1, 2010). Gönenç et al. (1995) determined that swimming exercise of 4 weeks caused significant increases in SOD activity, and Birites et al. (1999) determined a significant increase in plasma SOD activity in the study conducted on football players whereas Marzatico et al. (1997) determined a significant increase in erythrocyte SOD activity in the study conducted on sprinters and marathon runners. Cavas et al. (2005) determined a significant increase in pre- and post-exercise SOD values in elite Turkish judoists, and Ortenbland et al. (1997) determined that the SOD activity in exercised players is higher than under-exercised players. Taş et al. (2018) determined that 6-week sprint exercises increased SOD levels. Tonkonogi et al. (2000) determined that endurance exercises of 6 weeks do not result in change in SOD activity in males and females, and Watson et al. (2005) did not found any statistically significant in SOD activity of university students who regularly exercise. Belviranlı et al. (2017) introduced high-altitude exercise to elite pentathletes however reported that there was no change in SOD value, and Tiidus et al. (2000) reported that medium-intensity bicycle exercise for 8 weeks had no change in SOD activity. In our study, it is considered that in terms of SOD value, the second measurement significantly decreases compared to the first and third measurement, which resulted from free radical formation caused by the effect of exercise. However, in the third measurement, it is considered that the amount of SOD causes an increase in the amount of enzyme, with the positive effect of exercise.

GSH is an enzymatic antioxidant that protects tissues from oxidative damage during exercise (Taş, Soslu \& Kıyıcı, 2018). It forms a protective effect against lipid peroxidation by reducing hydrogen peroxide and organic peroxides (Kurutaş 2001). Andersson et al. (2009) reported that the elite female football players had a lower GSH rate at the end of the match. Bulduk (2010) determined that plasma GSH levels of female volleyball players were significantly lower at the end of the exercise test, and Tessier et al. (1995) determined that plasma GSH rate decreased following maximal aerobic capacity test. Although Gohil et al. (1988) reported that GSH levels in the blood decreased as a result of sub-maximal exercise, Camus et al. (1994) and Marin et al. (1990) determined no change in GSH levels in the plasma following exercise. In our study, although no statistically significant difference was found in the first, second and third measurement of the GSH level, it is considered that it increased the GSH amount in the third measurement and this increase resulted from positive effect of the exercise.

CAT enzyme is located in the mitochondria of the hepatocytes, erythrocyte cytoplasm and peroxisomes of other cells and it neutralizes $\mathrm{H} 2 \mathrm{O} 2$ by turning into water and oxygen (Armstrong 1998). Kiy1c1 and Kishal1 (2010) reported that there was an increase of CAT level in alpine skiers however this was not statistically significant. Tauler et al. (2005) did not determine any differences in resting CAT activity in amateur (athlete, cyclist) and professional (cyclist) athletes in several exercise tests. Tiidus et al. (1996) determined the aerobic exercise of 8 weeks did not change the CAT level, and Miyazaki et al. (2001), Gül et al. (2006), Balakrishnan and Anuradha (1998) determined no change in CAT enzyme 
activity. However Somani et al. (1995), Taş et al. (2018), Ohno et al. (1988) determined an increase in CAT activity in their studies, whereas Hong et al. (1995) and Mana et al. (2003) determined a decrease in CAT activity in their studies. Aguilo et al. (2000) reported that CAT enzyme declined as a result of sub-maximal (80\% maxVO2) exercise test in marathon runners. Revan (2007) reported that continuous runs significantly decreased the resting CAT values whereas there was no statistically significant difference in CAT values for the exhaustion exercise. In our study, no statistically significant difference was determined in the first, second and third measurement of the CAT activity however, there was an increase in the second measurement, and it is considered that this increased the CAT activity level formed with positive effect of the exercise.

Free radicals react with the phospholipid layer in the cell membranes, causing cellular damage. As a result of these reactions, measurable end products are released, and the most primary end product is MDA. In several studies, the free radical production resulting from overloading and different results are achieved. Tuna (2010) reported that MDA level decreased pre- and post-exercise and following exercise and 24 hours after exercise whereas Revan (2007) reported that the same decreased after exhaustion exercise, Alessio and Goldfarb (1988) reported that MDA levels increased following acute exercise and there was no increase in the exercise group. Taş et al. (2018) determined that MDA level decreased as a result of sprint exercises for football players. Gupta et al. (2009) determined higher serum MDA activity compared to sedentaries in elite bicyclists following an exhaustion exercise. Marzatico et al. (1997) found in their studies that plasma MDA on marathon runners who trained at high level and sprinters that trained sprint exercise at high level are high. Marini et al. (2007) determined that plasma MDA level was higher than the control group. In our study, the second measurement of MDA level was higher than the first and third measurements, and it is considered that the antioxidant level was decreased against oxidative stress formed with the effect of exercise and it increased MDA level. In the last measurement, the MDA level increased the antioxidant level with the positive effect of the exercise, and it is considered that this caused a decrease in MDA level.

Therefore to avoid or minimize deleterious affects of exercise induced oxidative stress the antioxidant capacity of the cell must be increased. Core exercises increased oxygen consumption which causes free radical formation. It was determined that detrimental effects of this free radical formation was repressed by increasing SOD activity value and it decreased MDA which is free radical parameters. It is thought that increasing antioxidant level via exercise can effect athlete performance positively.

\section{References}

Aguilo, A., Tauler, P., Gimeno, I., Fuentespina, E., \& Pons, A. (2000). Changes in erythrocyte antioxidant enzymes during prolonged submaximal exercise. Biofactors, 11(1-2), 27-30. https://doi.org/10.1002/biof.5520110108

Akdemir, E. F. N., Gülçin, İ., Karagöz., B., Soslu., R., \& Alwasel, S. H. (2016). Comparative study on the antioxidant effects of hesperidin and ellagic acid against skeletal muscle ischemia/reperfusion injury. Journal Of Enzyme Inhibition And Medicinal Chemistry, 3 (sup4), 114-118. https://doi.org/10.1080/14756366.2016.1220378

Alessio, H. M., \& Goldfarb, A. H. (1988). Lipid peroxidation and scavenger enzymes during exercise: adaptive response to training. J. Appl. Physiol., 64(4), 1333-1336. https://doi.org/10.1152/jappl.1988.64.4.1333

Anderson, K. G., \& Behm, D. G. (2004). Maintence of EMG activity and loss of force output with instability. The Journal of Strength and Conditioning Research, 18(3), 637-640.

Andersson, H., Karlsen, A., Blomhoff, R., Raastad, T., \& Kadi, F. (2009). Plasma antioxidant responses and oxidative stress following a soccer game in elite female players. Scand. J. Med. Sci. Sports, 35-42.

Balakrishnan, S. D., \& Anuradha, C. V. (1998). Exercise depletion of antioxidants and antioxidant manipulation. Cell Biochem Funct., 16(4), 269-275. https://doi.org/10.1002/(SICI)1099-0844(1998120)16:4<269::AID-CBF797>3.0.CO;2-B

Banerjee, A. K., Mandal, A., Chanda, D., \& Chakraborti, S. (2003). Oxidant, antioxidant and physical exercise. Mol. Cell Biochem.. 253(1-2), 307-312. https://doi.org/10.1023/A:1026032404105

Belviranlı, M., Okudan N., Kabak, B., Erdoğan, M., Karanfilci, M., \& Ada, M. A. (2017). Yüksek irtifa antrenmanının pentatlon sporcularında oksidatif stres ve antioksidan savunma belirteçleri üzerine etkisi. Genel Tip. Derg., 27(3), 95-99.

Brites, F. D., Evelson, P. A., Christiansen, M. G., Nicol, M. F., Basilico, M. J., Wilkinski, R. W., \& Llesuy, S. F. (1999). Soccer players under regular training show oxidative stres but an improved plasma antioxidant status. Clin. Sci. 96, 381-385. https://doi.org/10.1042/cs0960381

Bulduk, E. Ö. (2010). Bayan Sporcularda 20 Metre Mekik Koşu Testinin Oksidatif Stres Ve Antioksidan Düzeyleri Üzerine Etkisinin İncelenmesi. T.C. Selçuk Üniversitesi Sağlık Bilimleri Enstitüsü Doktora Tezi. Konya 
Camus, G., Felekidis, A., Pincemail, J., Deby-Dupont, G., Deby, C., Juchmes-Ferir, A., Lejeune, R., \& Lamy, M. (1994). Blood levels of reduced/oxidized glutathione and plasma concentration of ascorbic acid during eccentric and concentric exercises of similar energy cost. Arch Int Physiol Biochim Biophys. Jan-Feb; 102(1), 67-70.

Cavas, L., Arpinar, P., \& Yurdakoc, K. (2005). Possible interactions between antioxidant enzymes and free sialic acids in saliva: A preliminary study on elite judoists. Int. J. of Sports Medicine, 26, 832-835. https://doi.org/10.1055/s-2005-837465

Cazzola, R., Russo-Volpe, S., Cervato, G., \& Cestaro, B. (2003). Biochemical assessments of oxidative stress, erythrocyte membrane fluidity and antioxidant status in professional soccer players and sedentary controls. Eur. $J$. Clin. Invest., 33(10), 924-930. https://doi.org/10.1046/j.1365-2362.2003.01227.x

Comerford, M. J. (2006). Clinical Assessment of Stability Dysfunction-Performance Matrix.

Evelson, P., Gambino, G., Travacio, M., Jaita, G., Verona, J., Maroncelli, C., Wikinski, S. R., \& Brites, L. F. (2002). Higher antioxidant defences in plasma and low density lipoproteins from rugby players. Eur. J. Clin. Invest., 32(11), 818-825. https://doi.org/10.1046/j.1365-2362.2002.01057.x

Gohil, K., Viguie, C., Stanley, W. C., Brooks, G. A., \& Packer, L. (1988). Blood glutathione oxidation during human exercise. J. Appl. Physiol., Jan; 64(1), 115-119.

Gönenç, S., Açıkgöz, O., Emin, I., \& Özgönül, H. (1995). Çocuklarda 4 haftalık yüzme egzersizinin antioksidan enzimler ve lipid peroksidasyonuna etkisi. Spor Hekimliği Dergisi. 30(4), 209-215.

Gül, M., Demircan, B., Taysi, S., Oztasan, N., Gümüştekin, K., Siktar, E., ...\& Dane, S. (2006). Effects of endurance training and acute exhaustive exercise on antioxidant defense mechanisms in rat heart. Comp. Biochem. Physiol. A Mol. Integr. Physiol., 143, 239-245. https://doi.org/10.1016/j.cbpa.2005.12.001

Gülçin, İ. (2010). Antioxidant properties of resveratrol: A structure-activity insight. Innov. Food Sci. Emerg., 11, 210-218. https://doi.org/10.1016/j.ifset.2009.07.002

Gupta, C., Pradeep, H., \& Singh, B. (2009). Effect of Vitamin Supplementation on Exercise Induced Oxidative Stress in Trained Elite Indian Cyclists. Am. J. Biomed. Sci., 1(2), 166-170. https://doi.org/10.5099/aj090200166

Hodges, P. W., \& Richardson, C. A. (1996). In efficient muscular stabilization of the lumbar spine associated with low back pain. A motor control evaluation of transversus abdominis. Spine, 21(22), 2640-2650. https://doi.org/10.1097/00007632-199611150-00014

Kıyıcı, F., \& Kishalı, N. F. (2010). Alp Disiplini Kayakçılarında Sürat Egzersizleri Sonrası Kan Antioksidan Düzeylerinin İncelenmesi. Atabesbd., 12(1), 1-9.

Knez, W. L., Jenkins, D. G., \& Coombes, J. S. (2007). Oxidative stress in half and full Ironman triathletes. Med. Sci. Sports Exerc., 39(2), 283-288. https://doi.org/10.1249/01.mss.0000246999.09718.0c

Kurutaş, E. (2001). Endosülfanın fare eritrosit antioksidan sistemleri ve malondialdehit düzeyleri üzerine etkisi. Çukurova Üniversitesi Tıp Fakültesi Dergisi, 26(1), 14-19.

Leetun, D. T., Ireland, M. L., Willson, J. D., Ballantyne, B. T., \& Davis, I. M. (2004). Core stability measures as risk factors for lower extremity injury in athletes. Med. Sci. Sports Exerc., 36(6), 926-934. https://doi.org/10.1249/01.MSS.0000128145.75199.C3

Lehman, G. J. (2006). Resistance training for performance and injury prevention in golf. J. Can Chiropr Assoc. 50(1), $27-42$.

Manna, I., Jana, K., \& Samanta, P. K. (2003). Effect of intensive exerciseinduced testicular gametogenic and steroidogenic disorders in mature male Wistar strain rats: a correlative approach to oxidative stress. Acta Physiol Scand, 178(1), 33-40. https://doi.org/10.1046/j.1365-201X.2003.01095.x

Marini, E., Hänninen, O., Müller, D., \& Klinger, W. (1990). Influence of acute physical exercise on glutathione and lipid peroxides in blood of rat and man. Acta. Physiol. Hung., 76(1), 71-76.

Marzatico, F., Pansarasa, O., Bertorelli, L., Somenzini, L., \& Della, V. G. (1997). Blood free radical antioxidant enzymes and lipid peroxides following long-distance and lactacidemic performances in highly trained aerobic and sprint athletes. J. Sports Med. Phys. Fitness, 37(4), 235-239.

Miyazaki, H., Oh-ishi, S., Ookawara, T., Kizaki, T., Toshinai, K., Ha, S., ... \& Ohno, H. (2001). Strenuous endurance training in humans reduces oxidative stress following exhausting exercise. Eur. J. Appl. Physiol., 84(1-2), 1-6. https://doi.org/10.1007/s004210000342

Ohno, H., Yahata, T., Sato, Y., Yamamura, K., \& Taniguchi, N. (1988). Physical training and fasting erythrocyte 
activities of free radical scavenging enzyme systems in sedentary men. Eur J Appl Physiol Occup Physiol., 57(2), 173-176. https://doi.org/10.1007/BF00640658

Ortenblad, N., Madsen, K., \& Djurhuus, M. S. (1997). Antioxidant status and lipid peroxidation after short-term maximal exercise in trained and untrained humans. Am. J. Physiol., 272(4 Pt 2), R1258-63.

Palazzetti, S., Richard, M. J., Favier, A., \& Margaritis, I. (2003). Overloaded training increases exercise induced oxidative stress and damage. Can J. Appl.. Physiol., 28(4), 588-604. https://doi.org/10.1139/h03-045

Revan, S. (2007). Farklı Dayanıklılık Antrenmanlarının Oksıdatıf Stres Oluşumu ve Antıoksıdan Düzeyleri Üzerine Etkisi. T. C. Gazi Üniversitesi Sağlık Bilimleri Enstitüsü Beden Eğitimi ve Spor Anabilim Dalı. Ankara

Robertson, J. D., Maughan, R. J., Duthie, G. G., \& Morrice, P. C. (1991). Increased blood antioxidant systems of runners in response to training load. Clin Sci., 80(6), 611-618. https://doi.org/10.1042/cs0800611

Selamoglu, S., Turgay, F., Kayatekin, B. M., Gönenc, S., \& Yslegen, C. (2000). Aerobic and anaerobic training effects on the antioxidant enzymes of the blood. Acta Physiol Hung., 87(3), $267-273$. https://doi.org/10.1556/APhysiol.87.2000.3.5

Somani, S. M., Frank, S., \& Rybak, L. P. (1995). Responses of antioxidant system to acute and trained exercise in rat heart subcellular fractions. Pharmacol Biochem Behav., 51(4), 627-634. https://doi.org/10.1016/0091-3057(94)00427-K

Stephenson, J., \& Swank, A. M. (2004). Core training: Designing a program for anyone. Strength and Conditioning Journal, 26(6), 34-37.

Stokes, M., Hides, J., \& Nassiri, D. (1997). Musculoskeletal ultrasound imaging: diagnosis and treatment in rehabilitation. Physical Therapy Reviews, 2, 73-92. https://doi.org/10.1179/ptr.1997.2.2.73

Taş, M. (2011). Comparison of two different endurance training methods on glutathione s-transferase level. Afr. $J$. Biotechnol, 10(19), 3849-3853.

Taş, M., Soslu, R., \& Kiyici, F. (2018). The Effect Of Sıx Weeks Sprınt Traınıng On Serum Antıoxıdant Levels In Soccer Players. European Journal of Physical Education and Sport Science, 4(1), 35-45.

Tauler, P., Aguilo, A., Guix, P., Jimenez, F., Villa, G., Tur, J. A., Cordova, A., \& Pons, A. (2005). Pre-exercise antioxidant enzyme activities determine the antioxidant enzyme erythrocyte response to exercise. J. Sports Sci., 23(1), 5-13. https://doi.org/10.1080/02640410410001716724

Tessier, F., Margaritis, I., Richard, M. J., Moynot, C., \& Marconnet, P. (1995). Selenium and training effects on the glutathione system and aerobic performance. Med. Sci. Sports Exerc., Mar;27(3), 390-396.

Tiidus, P. M., Pushkarenko, J., \& Houston, M. E. (1996). Lackof antioxidant adaptation to short-term aerobic training in human muscle. Am. J. Physiol., 271, 832-836.

Tonkonogi, M., Walsh, B., Svensson, M., \& Sahlin, K. (2000). Mitochondrial function and antioxidative defence in human muscle: effects of endurance training and oxidative stress. J. Physiol., 528(2), 379-388. https://doi.org/10.1111/j.1469-7793.2000.00379.X

Tse, M. A., McManus, A. M., \& Masters, R. S. (2005). Development and validation of a core endurance intervention program: implications for performance in college-age rowers. J. Strength Cond. Res., 19(3), 547-552. https://doi.org/10.1519/00124278-200508000-00011

Urquhart, D. M., \& Hodges, P. W. (2005). Differential activity of regions of transversus abdominis during trunk rotation. Eur. Spine J., 14(4), 393-400. Epub 2004 Nov 30. https://doi.org/10.1007/s00586-004-0799-9

Warburton, D. E. R., Nicol, C. W., \& Bredin, S. S. D. (2006). Health benefits of physical activity: The evidence. CMAJ. 174(6), 801-809. https://doi.org/10.1503/cmaj.051351

Watson, T. A., MacDonald-Wicks, L. K., \& Garg, M. L. (2005). Oxidative stres and antioxidants in athletes under taking regular exercise training. Int. J. Sport Nutr Exerc Metab., 15(2), 131-146.

https://doi.org/10.1123/ijsnem.15.2.131

\section{Copyrights}

Copyright for this article is retained by the author(s), with first publication rights granted to the journal.

This is an open-access article distributed under the terms and conditions of the Creative Commons Attribution license which permits unrestricted use, distribution, and reproduction in any medium, provided the original work is properly cited. 